RESEARCH NOTE

\title{
Efficient protocols for the extraction of microbial DNA from the rhizosphere of hydrophilic forests in Chile
}

Pablo Cáceres ${ }^{1}$, Cecilia Corderoํ, Gloria González¹, Karla Quiroz², Juan

C. Bobadilla ${ }^{1}$, Carmen Bravo ${ }^{1}$, Peter D.S. Caligari ${ }^{3}$, Basilio Carrasco ${ }^{4}$, and Rolando García-Gonzales ${ }^{1}$

${ }^{1}$ Facultad de Ciencias Agrarias y Forestales. Universidad Católica del Maule. Ave. San Miguel, 3605, Talca, Chile.

${ }^{2}$ Facultad de Agronomía. ${ }^{3}$ Instituto de Biología Vegetal y Biotecnología. Universidad de Talca. Ave. Lircay s/n. Talca, Chile.

${ }^{4}$ Facultad de Agronomía e Ingeniería Forestal. Pontificia Universidad Católica de Chile. Casilla 306, Santiago, Chile.

\begin{abstract}
P. Cáceres, C. Cordero, G. González, K. Quiroz, J.C. Bobadilla, C. Bravo, P.D.S. Caligari, B. Carrasco, and R. García-Gonzáles. 2012. Efficient protocols for the extraction of microbial DNA from the rhizosphere of hydrophilic forests in Chile. Cien. Inv. Agr. 38(3): 585-592. A lysis buffer-based protocol (Protocol BA), a modified lysis buffer-based protocol (Protocol BA Mod) and a commercial extraction kit (Protocol PS Kit) (Power Soil, Mo bio Laboratories, CA USA) were each evaluated for their ability to produce highquality DNA with yields sufficient to allow its use in biodiversity studies. Similarly, the effect of liquid nitrogen on the process of cell disruption in all of the protocols that were studied. DNA yields ranged from $12.4 \mathrm{ng} \mathrm{g}^{-1}$ of processed soil to $9620 \mathrm{ng} \mathrm{g}^{-1} \mathrm{using}$ the modified lysis buffer and commercial extraction kit, respectively. The quality of the DNA was determined by the ability of the DNA to produce efficient and reproducible polymerase chain reaction (PCR) products, using primers for universal $16 \mathrm{~S}$ and $18 \mathrm{~S}$ ribosomal RNA regions from bacteria and fungi, respectively. High-quality DNA was obtained to run PCRs in all protocols, but the efficiency of the method depended on the dilution of the DNA prior to performing the PCR. The three extraction methods generated PCR products with $90 \%$ efficiency. The DNA produced with the commercial kit was able to produce the highest PCR efficiency (95\%) when the $10^{-1}$ dilution was used. The method based on the use of lysis buffer produced the highest efficiency $(90 \%)$ using a $10^{-2}$ dilution. Meanwhile, the modified lysis buffer-based protocol generated the highest efficiency of PCR products using the $10^{-3}$ dilution factor with $95 \%$ of efficiency. For the first time, reliable and efficient DNA isolation from the rhizosphere of hydrolic forest is documented, enabling a wide range of applications for this technique.
\end{abstract}

Key words: hydrophilic forests, 16S ribosomal RNA, PCR, rhizosphere, soil DNA extraction.

\section{Introduction}

Chile has just over 75 million hectares of national territory, of which 13.4 million are covered by native forest, 14.1 million comprise protected

Received April 14, 2011. Accepted October, 282011. Corresponding author: rgarciag@ucm.cl areas, and 2.1 million are occupied by artificial plantations. Pinus radiata represents $75 \%$ of the total planted forests, while a remaining $17 \%$ is planted with Eucalyptus spp. Only 5.9 million hectares out of the 13.4 million hectares of native forests are considered to be productive forests, according to the cadastre prepared by Coorporación Nacional Forestal (CONAF) and Comisión 
Nacional del Medio Ambiente (CONAMA). Forests that have greater coverage in the country are Siempreverde (4.3 million hectares), Lenga (3.4 thousand hectares), Coihue de Magallanes (1.8 thousand hectares) and Roble-Raulí-Coihue (1.3 million hectares) (CONAF, 1999).

The Chilean native forest holds a huge potential for social, cultural and economic development for the country. An estimated $20 \%$ of the native forests are owned by smallholders (Catalan et al., 2006). For this reason, sustainable forest management is a positive step towards the implementation of silvicultural methods tailored to each forest formation, also considering the needs of owners.

Spatial heterogeneity of soil is caused by the presence of plants in many types of terrestrial ecosystems (Zong et al., 2007). The soil is a very appropriate environment for the development of both eukaryotic (algae, fungi, protozoa) and prokaryotic (bacteria and archaea) microorganisms. These microorganisms are not randomly distributed but follow spatial patterns of aggregation at different scales (from $\mathrm{nm}$ to $\mathrm{km}$ ) that overlap each other. This structure is due to the effect of different control factors and is fully dynamic, with the following being some of the more important variables: $\mathrm{pH}$, water content, soil structure, presence of roots, climatic variations and biotic activity (Ettema et al., 2002).

The recent use of molecular techniques on soil samples has opened the way to the study of previously unexplored microbial communities (Eldor, 2007). Nucleic acid analysis has an advantage over other methods, as it reduces the time that is needed for samples to be processed, thus eliminating the requirement for the growth of microorganisms in nutrient media, a step that may make the outcomes non-representative of the actual situation in the soil (Eldor, 2007).

DNA extraction protocols often result in inadequate cell lysis and co-extraction of humic acids that, due to their similar physicochemical properties, prevent the correct hybridization of primers to template DNA, inhibit PCR amplification and restriction enzyme digestion. The same processes are also influenced by the phenolic groups of the humic acids, which denature proteins by bonding to amides. Furthermore, these molecules can be oxidized to form quinones that bind covalently to DNA (Lakay et al., 2007). The important factors to consider in regard to DNA extraction are as follows: (1) efficiency, which is accomplished by physical, chemical and enzymatic processes to ensure rupture of the resistant cell structures that are characteristic of some soil microorganisms or spores and (2) the removal of contaminants (e.g., humic acids) that are extracted together with nucleic acids and interfere with subsequent molecular analysis (O’Donnell et al., 1999).

The cell disruption protocols can be classified into two categories: those in which the cells are lysed within the soil (direct extraction) and those in which the cells are removed from the soil mix and the extraction is performed on isolated cells (Courtois, 2001). The technique of direct lysis, which was used in this study, is the most widely used because it gives a higher DNA yield and has less bias with respect to the diversity of the microbial community (Miller et al., 1999). Direct extraction methods include different protocols such as grinding in liquid nitrogen, mixing along with homogenization using short homogenization times and heat-shock treatment in a microwave oven with different chemical extractants, such as the ionic detergent sodium dodecyl sulfate (SDS), which acts by dissolving the hydrophobic material in the cells. The material is then subjected to heat with chelating agents such as ethylenediaminetetraacetic acid (EDTA) or Chelex 100 (Robe et al., 2003; Lakay et al., 2007).

The aim of this study was to establish a rapid, efficient and reliable method for the extraction of high-quality total genomic DNA from the rhizosphere of hydrophilic forests by evaluating three different methods for cell disruption and DNA extraction, as well as the use of liquid nitrogen 
during the cell lysis step. As the efficient extraction of soil DNA from the rhizosphere of hydrophilic forests in Chile has never been reported before, this technique will open up new opportunities in metagenomics and other studies involving soil microorganisms associated with native trees.

\section{Materials and methods}

\section{Soil sampling}

Samples were derived from a fragment of degraded material collected from a hydrophilic forest that grows on a sandy and loamy soil, with granulated particles that were both medium and small in size according to Centro de Informaciones de Recursos Naturales (CIREN-CORFO, 1964). The study was conducted on a plot of humid forest placed around the Convento Viejo dam, near the city of Chimbarongo, Chile (34 46' 40"; 71' 3' 45'). Sampling was performed from the rhizosphere by collecting the soil near the roots (a maximum of 5 $\mathrm{cm}$ from the root) and $10 \mathrm{~cm}$ from the soil surface. Rhizospheric soil samples were randomly taken from beneath five dominant tree species common in this type of Chilean forest: Luma chequen (Mol. A. Gray (Chequén), Blepharocalyx cruckshanksii (H. et A.) Nied. (Temu), Myrceugenia exsucca (DC.) Berg (Pitra), Drimys winteri J.R. Forst. \& G. Forst (Canelo) and Crinodendron patagua Mol. (Patagua).

All the samples were sealed in plastic bags and transported on ice. In the laboratory, samples were stored at $-80^{\circ} \mathrm{C}$ (Thermo, Model 702, Ohio, USA) until use.

\section{DNA extraction}

For DNA extraction, five soil samples for each treatment were collected in duplicate. The DNA extraction was performed on $500 \mathrm{mg}$ of frozen soil samples, previously stored at $-80{ }^{\circ} \mathrm{C}$. The effect of including liquid nitrogen while grinding the samples during the first steps of DNA extraction was evaluated by considering the DNA yield and its quality. Soil samples were macerated with or without liquid nitrogen. The liquid nitrogentreated samples were macerated to obtain a homogeneous powder. Samples being macerated without liquid nitrogen were briefly frozen at -80 ${ }^{\circ} \mathrm{C}$ at five-min intervals during maceration until a homogeneous mix was obtained. After that, total rhizospheric DNA was obtained by using three different methods. Two of these methods (called BA and BA Mod for this study) were adapted from Edwards et al. (1991) as previously reported (Cordero et al., 2011). The third extraction method was performed with the Power Soil extraction kit (MoBio Laboratories Inc., CA, USA) (called PS Kit for this study) according to the manufacturer's instructions.

Total DNA isolated by each protocol was checked by electrophoresis in agarose $(1 \% \mathrm{w} / \mathrm{v})$. The electrophoresis was performed at $110 \mathrm{~V}$ in $1 \mathrm{X}$ TAE running buffer. The concentration of DNA in each sample was measured directly in a spectrophotometer (Thermo Scientific, Nanodrop 2000, MA, USA) at $260 \mathrm{~nm}$. The absorbance ratio at the $260 \mathrm{~nm} / 280 \mathrm{~nm}$ wavelengths was scored for each sample.

Polymerase Chain Reaction (PCR). The quality of the DNA obtained was tested by its ability to produce polymerase chain reactions with primers for the 16S and 18S of bacterial and fungal ribosomal RNA (rRNA), respectively. The 16S rRNA was amplified using the primers 16SU1F1 (5'-ACTGCTTGCCTCCCGT-3') and 16SR2 (5'-CTACCAGGGTATCTAACT-3') (Paster et al., 1994). Amplicons from the $18 \mathrm{~S}$ rRNA from fungi were produced using the primers NS1 (5'-GTAGTCATATGCTTGTCTC) and NS2 (GGCTGCTGGCACCAGACTTGC) (White et al., 1990). Mixes for both PCR reactions were prepared as follows: $2 \mu \mathrm{L}$ of three dilution factors $\left(10^{-1}, 10^{-2}\right.$ or $\left.10^{-3}\right)$ from the sample DNA extracted by each method; $1.5 \mathrm{mM}$ of $\mathrm{MgCl}_{2 ;} 2.5 \mathrm{U}$ of Taq polymerase (Invitrogen, Sao Paulo, Brazil); 1.02 
$\mathrm{mM}$ of each primer; $0.2 \mathrm{mM}$ dNTP; $0.5 \mathrm{mg} \mathrm{mL}^{-1}$ of Bovine Serum Albumin (New England Biolabs Inc., IPSWICH, MA, USA); and PCR Buffer at $1 \mathrm{X}$. The final volume of the PCR mix was $25 \mu \mathrm{L}$, completed with double-distilled water. Sterile distilled water was used as a negative control. PCR was run in an automatic thermocycler (Thermo Electron Corporation, PX2-220, MA, USA), using the following programs:

Bacterial 16S rRNA: A denaturation step at $94{ }^{\circ} \mathrm{C}$ for 4 min followed by 45 cycles of $94{ }^{\circ} \mathrm{C}$ for 50 sec, annealing at $59.3{ }^{\circ} \mathrm{C}$ for $50 \mathrm{sec}$, and elongation at $72{ }^{\circ} \mathrm{C}$ for $45 \mathrm{sec}$. A final elongation step was performed at $72{ }^{\circ} \mathrm{C}$ for $8 \mathrm{~min}$.

Fungal18S rRNA: A denaturation step at $94{ }^{\circ} \mathrm{C}$ for $3 \mathrm{~min}$ followed by 45 cycles of $94{ }^{\circ} \mathrm{C}$ for 30 sec, annealing at $59^{\circ} \mathrm{C}$ for $1 \mathrm{~min}$ and elongation at $72{ }^{\circ} \mathrm{C}$ for $2 \mathrm{~min}$. A final elongation step was performed at $72{ }^{\circ} \mathrm{C}$ for $7 \mathrm{~min}$.

All the amplicons generated were visualized after electrophoresis in an agarose gel $(2 \% \mathrm{w} / \mathrm{v})$ using 1X TAE buffer.

Statistical analysis. The homogeneity of the variances was determined through Bartlett's Test $(\mathrm{P}<0.05)$. For the processing and analysis of normally distributed data, an ANOVA and the multiple range test of Tukey Honestly Significant Difference $(\mathrm{P}<0.05)$ were carried out. Non-parametric data were analyzed by the Kruskal-Wallis test $(\mathrm{P}<0.05)$.

\section{Results}

\section{Extraction of DNA}

All of the tested protocols were able to isolate total DNA from the rhizospheric environment of the sampled trees. However, the three protocols produced different amounts of DNA. The BA Mod protocol yielded higher concentrations of total DNA than the BA and PS Kit protocols (Figure 1). Concentra- tion of total DNA estimated by spectrophotometer ranged from $12.4 \mathrm{ng} \mathrm{g}^{-1}$ when the PS Kit was used to $9620 \mathrm{ng} \mathrm{g}^{-1}$ for the samples treated with the BA Mod protocol. The use of liquid nitrogen during sample maceration did not improve DNA yield for the BA and PS Kit protocols. However, using liquid nitrogen significantly increased the final concentration of DNA for the BA Mod protocol.

The absorbance ratio at the $260 \mathrm{~nm} / 280 \mathrm{~nm}$ wavelengths, an indicator of DNA quality, showed an average of 1.5 for DNA obtained using the BA and BA Mod protocols. The PS Kit protocol produced an absorbance ratio of 4.20, which is very high and could be interpreted as incomplete purification of DNA samples. An insignificant effect on DNA quality was obtained with the use of liquid nitrogen during the maceration of the rhizospheric soil samples.
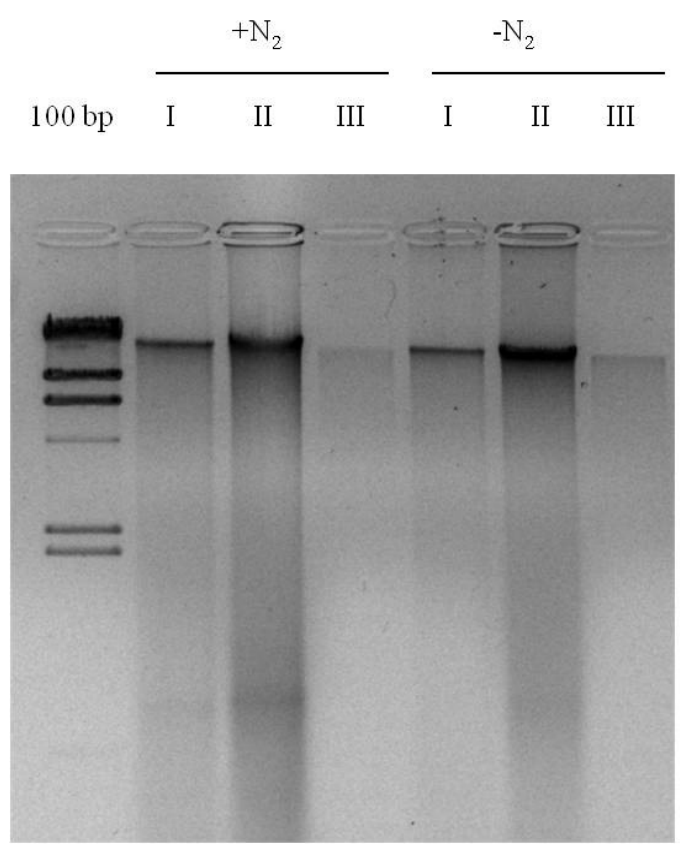

Figure 1. Extraction of DNA using different methods for one sample of soil. Lane 1: 100 bp DNA Ladder. Lanes 2, 3, 4: Extraction of DNA after grinding the soil samples with liquid nitrogen (I, BA protocol; II, BA mod protocol; III PS Kit protocol). Lanes 5, 6, 7: Extraction of DNA after grinding the soil samples without liquid nitrogen (I, BA protocol; II, BA mod protocol; III PS Kit protocol). 


\section{Amplification}

The quality of the purified rhizospheric DNA samples was evaluated by considering their ability to produce polymerase chain reaction amplicons. The results shown in Table 1 reveal that PCR performed using DNA obtained with the BA protocol diluted at $10^{-2}$ and $10^{-3}$ as template, successfully produced amplicons for the $16 \mathrm{~S}$ rDNA primers $(90 \%$ and $80 \%$, respectively) (Figure 2). However, the efficiency of amplicon production dropped to $25 \%$ when template DNA was diluted only by a factor of $10^{-1}$. A similar effect was observed for the BA Mod protocol, in which the dilution factor of $10^{-3}$ of the template DNA increased the amplification efficiency to $90 \%$. On the other hand, dilution of the DNA extracted with the PS Kit protocol below a $10^{-1}$ dilution factor reduced the PCR efficiency from $95 \%$ to $35 \%\left(10^{-2}\right)$ and zero $\left(10^{-3}\right)$ (Table 1$)$.

Considering the above results, template DNA was diluted using the best dilution factor obtained for each protocol, and $100 \%$ of amplicon production for the PCR of the 18S rDNA was obtained (Figure 3).

Table 1. Effect of the DNA extraction protocol and the dilution factor of the template DNA on the efficiency of the polymerase chain reaction (PCR). PCR was performed using the $16 \mathrm{~S}$ rRNA primers 16SU1F1 (5'-ACTGCTTGCCTCCCGT-3') and 16SR2 (5'-CTACCAGGGTATCTAACT-3').

\begin{tabular}{lcc}
\hline Protocol & Dilution factor & $\begin{array}{c}\text { Polymerase Chain Reaction efficiency } \\
(\%)\end{array}$ \\
\hline BA protocol & $1 / 10$ & $25.0 \mathrm{ab}$ \\
& $1 / 100$ & $90.0 \mathrm{c}$ \\
BA mod protocol & $1 / 1000$ & $80.0 \mathrm{c}$ \\
& $1 / 10$ & $0.0 \mathrm{a}$ \\
Kit PS protocol & $1 / 100$ & $10.0 \mathrm{a}$ \\
& $1 / 1000$ & $95.0 \mathrm{c}$ \\
$1 / 10$ & $95.0 \mathrm{c}$ \\
& $1 / 100$ & $35.0 \mathrm{~b}$ \\
\hline
\end{tabular}

Different letters indicate significant differences according to a Kruskal-Wallis test $(\mathrm{p}<0.05)$.

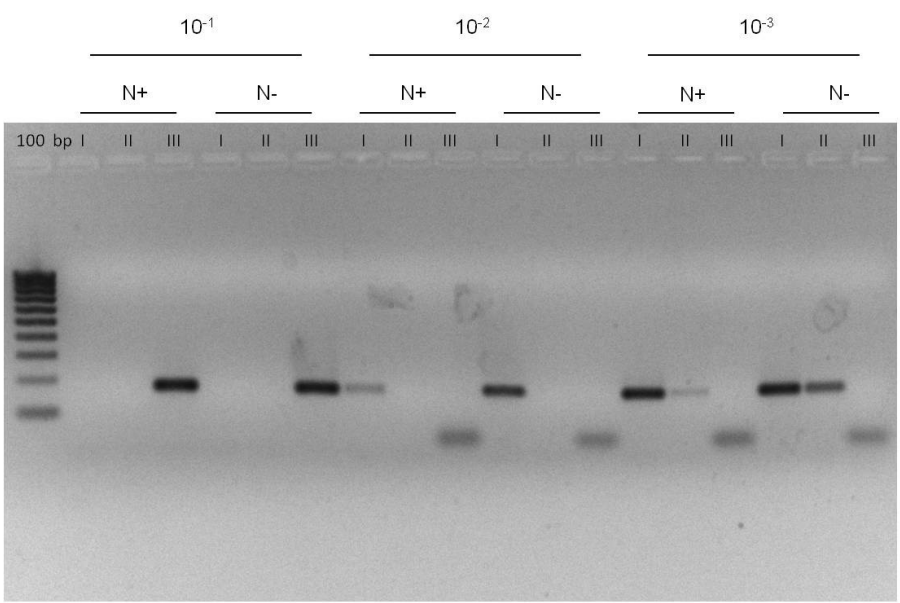

Figure 2. PCR products from rhizospheric DNA samples obtained with the different methods (I, BA protocol; II, BA mod protocol; III PS Kit protocol). PCR was performed using the primers 16S rRNA 16SU1F1 (5'-ACTGCTTGCCTCCCGT-3') and 16SR2 (5'-CTACCAGGGTATCTAACT-3'), which amplify an internal region of the 16S rRNA from bacteria. $\mathrm{N}+$, represents the use of liquid nitrogen during maceration of the samples; $\mathrm{N}$-, represents the maceration of the samples without the use of liquid nitrogen. 


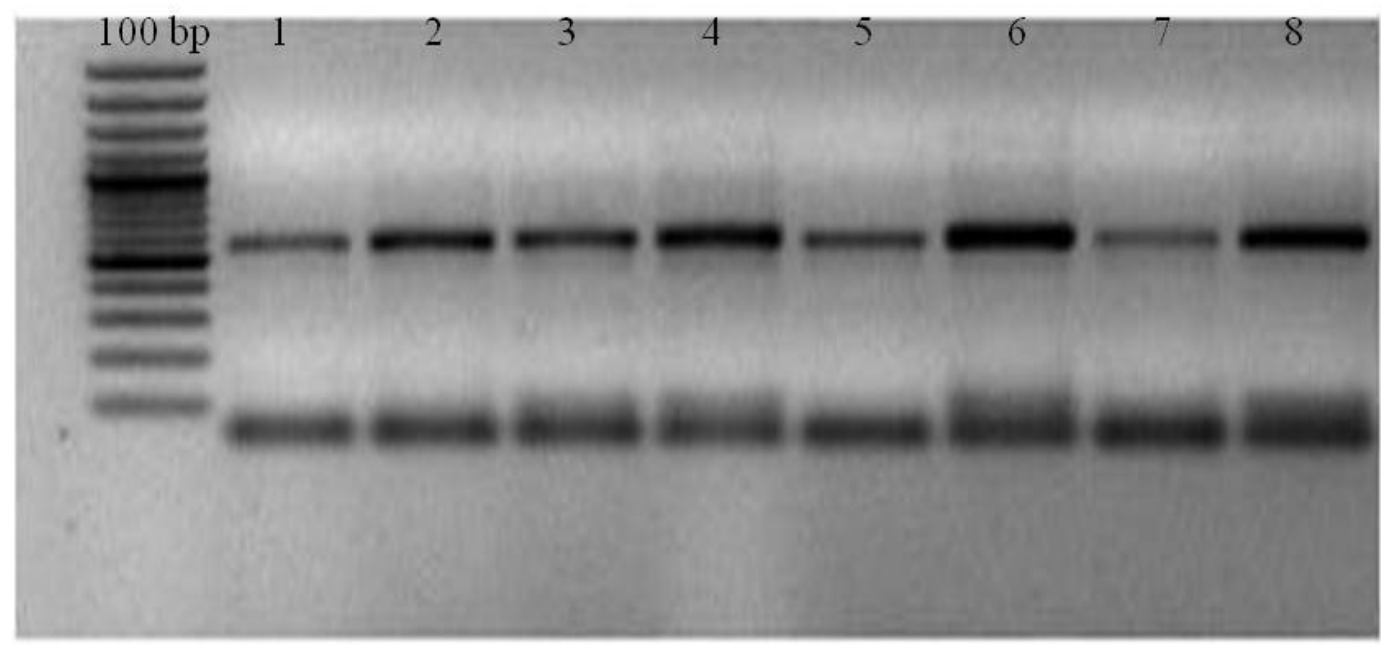

Figure 3. High efficiency of PCR reactions using a $10^{-2}$ dilution of the rhizospheric DNA samples obtained with the BA protocol as template. PCR was performed using the NS1 (5'-GTAGTCATATGCTTGTCTC) and NS2 (GGCTGCTGGCACCAGACTTGC) primers, which amplify an internal region of the 18S rRNA from fungi.

\section{Discussion}

The yield and quality of DNA are influenced by a number of factors that must be taken into consideration. The use of proteinase $\mathrm{K}$ at the end of the DNA extraction protocol has been demonstrated to produce high-quality DNA (Aras et al., 2003). It has also been found that organic solvents, such as phenol and chloroform, can increase DNA yield and that the use of liquid nitrogen during the extraction can affect the DNA present both in the microbial community of the rhizosphere and already free in the soil (Sagova-Mareckova et al., 2008).

Two of the tested protocols (BA and BA mod) showed an absorbance ratio for spectrophotometer readings at $260 \mathrm{~nm} / 280 \mathrm{~nm}$ of 1.5 , which is less than optimal for DNA samples (1.8), according to Sambrook et al. (1989). For DNA extraction protocols from soil samples based on the use of cetyl trimethyl ammonium bromide (CTAB) and polyvinylpolypyrrolidone (PVPP), the main problems of yield and quality of DNA have been associated with the failure to remove humic compounds, which are commonly present in the soil (Zhou et al., 1996). Most likely, the rhizosphere environment of the Chilean humid forests sampled in this study harbors low molecular weight organic matter and humic acids, which may affect the efficiency of DNA extraction and its quality. The high content of organic matter, as well as iron oxide, produced DNA extracts with a dark color which have been noted to cause problems when DNA is used in PCR protocols (Thakuria et al., 2008).

The PCR amplifications gave a suitable indicator of the quality of the DNA obtained by each protocol. It has been found that the enzyme Taq polymerase can be inhibited even when the source of DNA used as template is contaminated with less than $1 \mu \mathrm{g} \mathrm{mL}^{-1}$ of humic acid (Clegg et al., 1997). In these cases, the dilution of the original samples is highly recommended prior to the preparation of the PCR mixes. Application of DNA dilution for the different protocols gave different results, but at least for the BA and BA mod protocols, the reduction of the pollutant concentration in each sample increased the PCR efficiency. In addition, the use of bovine serum albumin (BSA) in the reaction mix of the PCR is recommended to improve the amplification efficiency (La Montagne et al., 2002), as this reagent reduces the inhibition of the Taq polymerase activity by organic and inorganic compounds (Mabru et al., 2004). 
It seems that DNA samples obtained by the BA mod protocol bring a higher amount of potential inhibitors, as PCR behaved better at higher dilutions, which is consistent with previous reports (Clegg et al., 1997). On the other hand, the PS Kit produced a cleaner DNA sample, but yield was very low, which could be a disadvantage if larger studies involving the analysis of soil DNA have to be performed.
Finally, the use of the BA protocol for DNA isolation from the rhizospheric environment of Chilean hydrophilic forest appears to be the most suitable. The yield of DNA, as well as the $260 \mathrm{~nm} / 280 \mathrm{~nm}$ absorbance ratio of the samples, is good enough to perform any genetic studies involving the soil DNA on a large scale. On the other hand, the use of liquid nitrogen is unnecessary as it did not give any worthwhile effects with this protocol.

\section{Resumen}

P. Cáceres, C. Cordero, G. González, K. Quiroz, J.C. Bobadilla, C. Bravo, P.D.S. Caligari, B. Carrasco y R. García-Gonzáles. 2012. Protocolos para la extracción eficiente de ADN microbiano a partir de la rizosfera del bosque hidrófilo en Chile. Cien. Inv.Agr. 39(3): 585-592. Se evaluó el uso de Buffer de lisis (Protocolo BA), Buffer de lisis modificado (Protocolo BA Mod) y el uso de kit comercial de extracción (Protocolo PS Kit) (Power Soil, Mo bio Laboratories, CA USA) y su efectividad para producir ADN de calidad biológica con rendimientos que permitan su uso en estudios de biodiversidad. De igual forma, se evaluó el efecto del nitrógeno líquido en el proceso de ruptura celular en todos los protocolos estudiados. Se obtuvieron rendimientos de ADN desde 12,4 hasta $9620 \mathrm{ng} \mathrm{g}^{-1}$ de suelo procesado utilizando los métodos basados en el buffer de lisis modificado y kit de extracción comercial. La calidad biológica del ADN se determinó mediante la habilidad del ADN para producir eficientes y reproducibles Reacciones en Cadena de la Polimerasa utilizando partidores del ADN ribosomal $16 \mathrm{~S}$ y $18 \mathrm{~S}$ de bacterias y hongos, respectivamente. Se obtuvo ADN de calidad biológica para PCR en todos los protocolos, pero la eficiencia del método dependió de la dilución del ADN previo al desarrollo de las PCRs. Los tres métodos de extracción generaron productos de PCR por encima del $90 \%$ de las muestras analizadas. Se observó que el factor de dilución del ADN afecta la eficiencia de la técnica de PCR en los tres protocolos evaluados pues para la extracción con Kit comercial, la mayor eficiencia en el PCR se obtuvo cuando la dilución $10^{-1}$ fue utilizada. El método basado en el buffer de lisis produjo la mayor eficiencia (90\%) utilizando la dilución $10^{-2}$. Por otro lado, el protocolo buffer de lisis modificado generó la más alta eficiencia utilizando la dilución $10^{-3}$ con un $95 \%$ de eficiencia. Los métodos evaluados permiten, por primera vez, la obtención eficiente y confiable de ADN de alta calidad a partir la rizósfera del bosque hidrófilo chileno.

Palabras clave: bosques húmedos, $16 \mathrm{~S}$ ribosomal, extracción ADN de suelo, PCR, rizósfera.

\section{References}

Aras, S., A. Duran, and G. Yenilmez. 2003. Isolation of DNA for RAPD analysis from dry leaf material of some Hesperis L. specimens. Plant Molecular Biology Reporter 21: 461a-461f.

Catalán, R., P. Wilken, A. Kandzior, D. Tecklin, and H. Burschel. 2006. Bosques y comunidades del
Sur de Chile. Primera Edición. Editorial Universitaria, Santiago, Chile. 90 pp.

CIREN-CORFO. 1964. Suelos. Descripciones Proyecto Aerofotogramétrico Chile-OEA-BID. Centro de Información de Recursos Naturales (CIREN), Corporación de Fomento de la Producción (CORFO). Santiago, Chile. Publicación No 2. 307 pp. 
Clegg, C., D. K. Ritz, and B. S. Griffiths. 1997. Direct extraction of microbial community DNA from humified upland soils. Letters in Applied Microbioly 25: 30-33.

CONAF. 1999. Catastro y Evaluación de los Recursos Vegetacionales Nativos de Chile. Informe Nacional con variables ambientales, CONAF (Corporación Nacional Forestal)-CONAMA (Comisión Nacional de Medio Ambiente)-BIRF (Banco Internacional de Reconstrucción y Financiamiento), Universidad Austral de Chile, Pontificia Universidad Católica de Chile, Universidad Católica de Temuco. Santiago, Chile. 89 pp.

Cordero, C., P. Cáceres, G. González, C. Bravo, K. Quiroz, B. Carrasco, R. García-González. 2011. Rapid and efficient detection of Black truffle (Tuber melanosporum) in soil and roots from artificially inoculated plants. Chilean Journal of Agricultural Research 71: 488-494.

Courtois, S., Å. Frostegård, P. Göransson, G. Depret, P. Jeannin, and P. Simonet. 2001. Quantification of bacterial subgroups in soil: comparison of DNA extracted directly from soil or from cells previously released by density gradient centrifugation. Environmental Microbiology 3: 431-439.

Edward, K., C. Johnston, and C. Thompson. 1991. A simple and rapid method for the preparation of plant genomic DNA for PCR analysis. Nucleic Acids Research 19: 1349.

Eldor, A.P. 2007. Soil microbiology, ecology and biochemistry. Third edition. Elsevier Academic Press. USA. 532 pp.

Ettema, C. H., and D. A. Wardle. 2002. Spatial soil ecology. Trends in Ecolgy \& Evolution 17: 177-183.

Lakay, F.M., A. Botha, and B.A. Prior. 2007. Comparative analysis of environmental DNA extraction and purification methods from different humic acid-rich soils. Journal of Applied Microbioly 102 : 265-273.

La Montagne, M.G., F.C. Michel Jr., P.A. Holden, and C.A. Reddy. 2002. Evaluation of extraction and purification methods for obtaining PCRamplifiable DNA from compost for microbial community analysis. Journal Microbiological Methods 49: 255-264.

Mabru, D., J.P. Douet, A. Mouton, C. Dupre, J.M. Ricard, B. Médina, M. Castroviejo, and Chevalier.
2004. PCR-RFLP using a SNP on the mitochondr ial Lsu-rDNA as an easy method to differentiate Tuber melanosporum (Perigord truffle) and other truffle species in cans. International Journal of Food Microbiology 94: 3342.

Miller, D.N., J.E. Bryant, E.L. Madsen, and W.C. Ghiorse. 1999. Evaluation and Optimization of DNA extraction and purification procedures for soil and sediment samples. Applied Environmental Microbioly 65: 4715-472.

O’Donell, A. G., and H. E. Görres. 1999. 16S rDNA methods in soil microbiology. Current Opinion in Biotechnology 10: 225-229.

Paster, B.J., F.E. Dewhirst, I. Olsen, and G. J. Fraser. 1994. Phylogeny of bacteroides, Prevotella, and Porphyromonas spp. and related bacteria. Journal of Bacteriolgy 176: 725-732.

Robe, P., R. Nalin, C. Capellano, T.M. Vogel, and P. Simonet. 2003. Extraction of DNA from soil. European Journal of Soil Biology 39: 183-190.

Sagova-Mareckova, M., L. Cermak, J. Novotna, K. P1hackova, J. Forstova, and J. Kopecky. 2008. Innovative methods for soil DNA purification tested in soil with widely differing characteristics. Applied Environmental Microbiology 74: 2902-2907.

Sambrook, J., E.F. Fritsch, and T. Maniatis. 1989. Molecular Cloning: A Laboratory Manual. Second edition. Cold Spring Harbor Laboratory Press, New York, USA. 6.60 pp.

Thakuria, D., O. Shmidt, M. Mac Siúrtáin, D. Egan, and F.M. Doohan. 2008. Importance of DNA quality in comparative soil microbial community structure analyses. Soil Biology \& Biochemistry 40: 1390-1403.

White, T., T. Bruns, S. Lee, and J. W. Taylor. 1990. Amplification and direct sequencing of fungal ribosomal RNA genes for phylogenetics. In: Innis, M.A., Gelfand, D.H. Sninsky, J.J. and White T.J. (eds.). PCR protocols: a guide to methods and applications. Academic Press, San Diego. p. 315-322.

Zhou, J., M.A. Bruns, and J.M. Tiedje. 1996. DNA recovery from soils of diverse composition. Applied Environmental Microbiology 62: 316-322.

Zong, M., X. Han, Z. Zhang, X. Zhang, and R. Wang. 2007. DNA Recovery from soil in restoration area and indicated iodiversity. Ekológia 26: 381-389. 